\title{
FRANK'S SIGN AS A RISK FACTOR FOR CEREBROVASGULAR DISEASE
}

\author{
Josip Glavić1 ${ }^{1}$ Denis Čerimagić ${ }^{2}$ Arijana Lovrenčić-Huzjan ${ }^{3}$, Vlasta Vukovićc and Vida Demarin ${ }^{3}$ \\ ${ }^{1}$ Glavić Polyclinic of Neurlogy, Dubrovnik, ${ }^{2}$ Department of Neurology, Dubrovnik General Hospital, Dubrovnik; \\ ${ }^{3}$ University Department of Neurology, Sestre milosrdnice University Hospital, Zagreb, Croatia
}

\begin{abstract}
SUMMARY - Frank's sign is a dermatological marker, which has in many studies correlated with coronary heart disease. The aim of the study carried out in a sample of 60 subjects was to define whether Frank's sign belongs to the group of risk factors for cerebrovascular disease. The subjects with the presence of Frank's sign were assigned to group A, and those without Frank's sign to group B. All study subjects underwent color Doppler examination of carotid arteries and determination of their common carotid artery intimal wall thickness (ACG IMT). The value exceeding $0.9 \mathrm{~mm}$ was considered as an ACC IMT increase. Statistical analysis by use of Pearson's $\chi^{2}$-test yielded a value of 11.279 and $p=0.001$. Assessment of the Frank's sign value in predicting increased ACC IMT showed a sensitivity of $73 \%$, specificity of $70 \%$, positive predictive value of $71 \%$ and negative predictive value of $72 \%$. The study indicated a statistically significant correlation between Frank's sign and increased ACC IMT, supporting the hypothesis according to which this marker is an uncontrollable risk factor for cerebrovascular disease.
\end{abstract}

Key words: Ear, external - anatomy and histology; Coronary disease - epidemiology; Cerebrovascular disorders pathology; Cerebrovascular disorders - etiology; Risk factors; Incidence

\section{Introduction}

Frank's sign (diagonal incisure of ear lobe) is a dermatological marker extending from the tragus usually at an angle of 45 degrees to the rear edge of the auricle ${ }^{1}$. Many studies published so far have defined a correlation of Frank's sign and coronary heart disease occurring due to advanced atherosclerosis ${ }^{1-7}$. Since atherosclerosis is a generalized disease, it could be concluded that Frank's sign occurs more frequently in patients with cerebrovascular disease. However, studies of this type have not yet been carried out. Increased common carotid artery intima media thickness (ACC IMT) is a substitute marker of atherosclerosis, meaning that its increased value represents a risk for the occurrence of heart attack and stroke. The aim of our study was to determine whether Frank's sign belongs to the group of risk

Correspondence to: Josip Glavić, MD, Glavić Polyclinic of Neurology, Ćire Carića 3, HR-20000 Dubrovnik, Croatia

E-mail: josko.glavic@inet.hr

Received July 19, 2006, accepted in revised form November 7, 2006 factors for cerebrovascular diseases such as race, sex or age. The null hypothesis was that there was no statistically important link between Frank's sign and increased ACC IMT, and accordingly that there was no risk of cerebrovascular disease.

\section{Subjects and Methods}

This prospective case-control study was carried out during April 2006 in a group of 60 patients undergoing examination at cerebrovascular laboratory of the Glavić Polyclinic of Neurology in Dubrovnik. Two groups were created, each containing 30 (11 female and 19 male) patients. Consecutive patients with ear lobe crease were included in the study. Women with earrings were not included in the study, due to the possibility of potential false Frank's sign. After including one patient with ear lobe crease (Frank's sign) in the first group, a consecutive sex- and age-matched control was included in the other group. In all subjects, one or more risk factors for the development of atherosclerosis were recorded. The two groups were comparable according to mean age. All 
subjects underwent carotid Doppler examination using a high-resolution ultrasound system Aloka 3500 Prosound plus (Aloka GmbH, Meerbusch, Germany) and semiautomated computer program for IMT evaluation. IMT values were measured by B-mode on ACC placed 1.5 $\mathrm{cm}$ proximally from carotid bifurcation. The ACC IMT above $0.9 \mathrm{~mm}$ was considered increased.

Result analysis was done by use of Mann-Whitney test, Pearson's $\chi^{2}$-test and contingency tables.

\section{Results}

The mean age was $65.7 \pm 12.2$ (range 53.5-77.9) years in group A (Frank's sign present) and 65.4 11.59 (range 53.8-76.9) years in group B (Frank's sign absent). Statistical analysis using Mann-Whitney test (comparison of data on two independent samples) yielded $z=-0.155$ and $\mathrm{p}=0.877$, indicating that there was no statistically significant between-group difference according to age. Statistical analysis using Pearson's $\chi^{2}$-test assessing statistical significance of frequencies in two samples was employed to estimate the possible correlation between Frank's sign and ACC IMT. This testing yielded values of 11.279 and $p=0.001$, showing statistical significance with a risk level of $0.1 \%$. Using the same test we checked whether there was either sex predominance in the presence of Frank's sign. This testing yielded $\chi^{2}=0 ; p=1.0$, meaning there was a comparable number of men and women with the sign. Assessment of the Frank's sign value in predicting increased ACC IMT by use of contingency table (Table 1) indicated a sensitivity of $73 \%$, specificity of $70 \%$, positive predictive value (PPV) of $71 \%$ and negative predictive value (NPV) of $72 \%$. The results obtained demonstrated that there was a statistically significant correlation between Frank's sign and increased ACC IMT as a marker of atherosclerosis. The sign itself was found to be a good predictor of the risk of cerebrovascular disease.

\section{Discussion}

In our study, we examined the correlation of Frank's sign and increased ACC IMT with the consequential risk of cerebrovascular disease. Our results showed that increased ACC IMT was most often found in patients with Frank's sign. In 1973, Frank noticed that many cardiac patients (especially those younger than 60 years of age) had unilateral or bilateral diagonal incisure of ear lobe ${ }^{1}$. In their anthropological study, Dharap et al. recorded the presence of this phenotypic marker in $31.1 \%$ of healthy men and 3.6\% of healthy women in Malay population $^{8}$. Many studies show that Frank's sign can be determined as a marker of atherosclerosis and a sign of elevated risk of coronary heart disease in asymptomatic individuals $^{1-7}$, with the exception of native American Indians, Oriental patients and children suffering from Beckwith's syndrome ${ }^{9}$. According to the results reported by Davis et al. ${ }^{10}$, and Kenny and Gilligan ${ }^{11}$, Frank's sign cannot be considered as a predictor of coronary disease. Bahcelioglu et al. demonstrated the association of Frank's sign with diabetes, hypertension, myocardial infarction and coronary disease in patients of both sex$\mathrm{es}^{12}$. Based on the presence of bilateral diagonal incisure of ear lobe on the statues of the Roman Emperor Hadrian, Petrakis poses a hypothesis according to which Hadrian died due to advanced coronary atherosclerosis and heart failure ${ }^{13}$. In the studies carried out by Crouse ${ }^{14}$ and Craven et al. ${ }^{15}$, a connection of coronary heart disease and carotid artery atherosclerotic changes was determined. O'Leary et al. found the increased ACC IMT to be directly connected with an elevated risk of myocardial infarction and stroke in adults with a negative history of cardiovascular disease ${ }^{16}$. The risk factors for atherosclerosis, which increase the ACC IMT values include arterial hypertension, elevated level of cholesterol and LDL cholesterol, smoking, diabetes, hematological parameters such as fibrinogen level, fibrinopeptide $\mathrm{A}$ and D-dimer, tissue plasminogen activator, serum copper value, homocysteine value, while no connection was found with alcohol consumption, triglyceride value or glycolysated hemoglobin $\left(\mathrm{HbA}_{1 \mathrm{c}}\right)$ in patients with diabetes ${ }^{17-20}$. Studies have shown that hormone replacement therapy in menopause has a protective effect, which means that it lowers the ACC IMT values ${ }^{21}$.

A possible limitation of the present study was that the number of patients was too small for multivariate analysis. On literature survey, we found no studies evaluating Frank's sign as a risk factor for cerebrovascular disease. To our knowledge, this was the first study of

Table 1. Evaluation of Frank's sign with identification of increased ACG IMT

\begin{tabular}{lccc}
\hline ACC IMT & Present & $\begin{array}{c}\text { Frank's sign } \\
\text { Absent }\end{array}$ & Total \\
\hline Increased & 22 & 9 & 31 \\
Normal & 8 & 21 & 29 \\
Total & 30 & 30 & 60 \\
\hline
\end{tabular}

ACC IMT $=$ common carotid artery intima-media thickness 
the kind, and we plan to confirm the results obtained in further studies in a larger number of patients. If our observations prove correct in a greater sample of subjects, we could add Frank's sign to the group of risk factors for the development of atherosclerosis. Since Frank's sign is a visible sign, preventive actions could then be taken.

\section{Conclusion}

The results of this study revealed a statistically significant correlation between the presence of Frank's sign and increased ACC IMT. The results of Frank's sign validity assessment were higher that those obtained in other similar studies carried out in subjects suffering from coronary heart disease, thus supporting our hypothesis that Frank's sign belongs to the group of uncontrollable risk factors for cerebrovascular disease such as race, sex or age.

\section{References}

1. FRANK ST. Aural sign of coronary-artery disease. N Engl J Med 1973;289:327-8.

2. MIRIĆ D, FABIJANIĆ D, GIUNIO L, ETEROVIĆ D, ČULIĆ V, BOŽIĆ I, HOZO I. Dermatological indicators of coronary risk: a case-control study. Int J Cardiol 1989;67:251-5.

3. KURI M, HAYASHI Y, KAGAWA K, TAKADA K, KAMIBAYASHI T, MASHIMO T. Evaluation of diagonal ear lobe crease as a marker of coronary artery disease: the use of this sign in preoperative assessment. Anaesthesia 2001;56:1160-2.

4. MIRIĆ D, RUMBOLDT Z, PAVIĆ M, KUZMANIĆ A, BAGATIN J. The role of the diagonal ear lobe crease in the clinical evaluation of coronary risk. Lijec Vjesn 1990;112:206-7.

5. DOERING C, RUHSENBERGER C, PHILLIPS DS. Ear lobe creases and heart disease. J Am Geriatr Soc 1977;25:183-5.

6. MOTAMED M, PELEKOUDAS N. The predictive value of diagonal ear-lobe crease sign. Int J Clin Pract 1998;52:305-6.

7. GUTIU I, el RIFAI C, MALLOZI M. Relation between diagonal ear lobe crease and ischemic chronic heart disease and the factors of coronary risk. Med Interne 1986;24:111-6.

8. DHARAP AS, SHARMA HS, THAN M. Ear lobe crease: incidence in healthy Malay population. Anthropol Anz 2000;58:30915.

9. ELLIOT WJ. Ear lobe crease and coronary artery disease: 1000 patients and review of the literature. Am J Med 1983;75:1024-32.
10. DAVIS TM, BALME M, JACKSON D, STUCCIO G, BRUCE DG. The diagonal ear lobe crease (Frank's sign) is not associated with coronary artery disease or retinopathy in type 2 diabetes: the Fremantle Diabetes Study. Aust N Z J Med 2000;30:573-7.

11. KENNY DJ, GILLIGAN D. Ear lobe crease and coronary artery disease in patients undergoing coronary arteriography. Cardiology 1989;76:293-8.

12. BAHCELIOGLU M, ISIK AF, DEMIREL B, SENOL E, AYCAN S. The diagonal ear lobe crease as a sign of some diseases. Saudi Med J 2005;26:947-51.

13. PETRAKIS NL. Diagonal ear lobe creases, type A behavior and the death of Emperor Hadrian (Medicine in Perspective). West J Med 1980;132:87-91.

14. CROUSE JR $3^{\text {rd }}$. Carotid and coronary atherosclerosis. What are the connections? Postgrad Med 1991;90:175-9.

15. CRAVEN TE, RYU JE, ESPELAND MA, KAHL FR, McKINNEY WM, TOOLE JF, McMAHAN MR, THOMPSON CJ, HEISS F, CROUSE JR $3^{\text {rd }}$. Evaluation of the associations between carotid artery atherosclerosis and coronary artery stenosis. A case-control study. Circulation 1990;82:1230-42.

16. O'LEARY DH, POLAK JF, KRONMAL RA, MANOLIO TA, BURKE GL, WOLFSON SK Jr. Carotid-artery intima and media thickness as a risk factor for myocardial infarction and stroke in older adults. Cardiovascular Health Study Collaborative Research Group. N Engl J Med 1999;340:14-22.

17. LOVRENČIĆ-HUZJAN A. Neurosonologic methods in stroke diagnosis. Acta Clin Croat 2004;42:42-4.

18. DEMARIN V, LOVRENČIĆ-HUZJAN A, ŠERIĆ V, VARGEKSOLTER V, TRKANJEC Z, VUKOVIĆ V, LUPRET V, KALOUSEK M, De SYO D, KADOJIĆ D, LUŠIĆ I, DIKANOVIĆ M, VITAS M. Recommendations for stroke management. Acta Clin Croat 2001;40:127-54.

19. DEMARIN V, LOVRENČIĆ-HUZJAN A, ŠERIĆ V, VARGEKSOLTER V, TRKANJEC Z, VUKOVIĆ V, LUPRET V, KALOUSEK M, De SYO D, KADOJIC D, LUSIC I, DIKANOVIC M, VITAS M. Recommendations for care of patients with cerebral accident. Part one: Organization of care for patients with cerebral accidents, treatment of cerebral accident and neurorehabilitation. Lijec Vjesn 2003;125:200-12.

20. DEMARIN V, LOVRENČIĆ-HUZJAN A, ŠERIĆ V, VARGEKSOLTER V, TRKANJEC Z, VUKOVIĆ V, LUPRET V, KALOUSEK M, De SYO D, KADOJIĆ D, LUŠIĆ I, DIKANOVIĆ M, VITAS M. Recommendations for management of patients with cerebral stroke. Part two: Primary and secondary prevention of cerebral stroke. Lijec Vjesn 2003;125:322-8.

21. PENTZ-VIDOVIĆ I, DEMARIN V, GRUBIŠIĆ G, KUNA K, LOVRENČIĆ-HUZJAN A. Carotid artery intima thickness and flow velocity after discontinuation of hormone replacement therapy in postmenopausal women: follow-up study. Croat Med J 2001:42:54-7. 
Sažetak

\section{FRANKOV ZNAK KAO ČIMBENIK RIZIKA CEREBROVASKULARNE BOLESTI}

\section{J. Glavic, D. Čerimagić, A. Lovrenčić-Huzjan, V. Vuković i V. Demarin}

Frankov znak je dermatološki biljeg koji je u brojnim studijama povezan s koronarnom bolešću srca. Cilj istraživanja provedenog na uzorku od 60 ispitanika bio je utvrditi pripada li Frankov znak čimbenicima rizika cerebrovaskularne bolesti. U skupinu A svrstani su ispitanici s prisutnim, a u skupinu B ispitanici s odsutnim Frankovim znakom te je svima napravljen obojeni Doppler karotidnih arterija i određena debljina intimalne stijenke (IMT) na zajedničkoj karotidnoj arteriji (ACC). Kao povećanje ACC IMT uzeta je vrijednost iznad $0,9 \mathrm{~mm}$. Statističkom analizom Pearsonovim $\chi^{2}$-testom dobivena je vrijednost od 11,279 i p=0,001. Procjenom vrijednosti Frankovog znaka u predviđanju povećanja ACC IMT utvrđena je osjetljivost od $73 \%$, specifičnost od $70 \%$, pozitivna prediktivna vrijednost od $71 \%$ i negativna prediktivna vrijednost od $72 \%$. Istraživanje je pokazalo statistički značajnu povezanost Frankovog znaka i povećanja ACC IMT, što podupire hipotezu prema kojoj je ovaj znak čimbenik rizika cerebrovaskularne bolesti na koji se ne može utjecati.

Ključne riječi: Uho, vanjsko - anatomija i histologija; Koronarna bolest - epidemiologija; Cerebrovaskularne bolesti - patologija; Cerebrovaskularne bolesti - etiologïa; Čimbenici risika; Incidencïa 